Jurnal Adat dan Budaya, Vol 3, No 1 Tahun 2021

ISSN: E-ISSN 2615-6156, P-ISSN: 2615-6113

Jurnal Homepage: https://ejournal.undiksha.ac.id/index.php/JABI/index

\title{
Muatan Nilai dalam Tradisi Pela Gandong di Maluku Tengah
}

\author{
Althien J Pesurnay 1 \\ ${ }_{1}^{1}$ MKH, FKHUM, Universitas Kristen Duta Wacana, Yogyakarta, Indonesia \\ e-mail: althienjohn@staff.ukdw.ac.id
}

\begin{abstract}
Abstrak
Indonesia merupakan negara yang dianugerahkan keragaman budaya. Sehingga, kearifan lokal hidup dalam tiap-tiap kebudayaan daerah. Tergerusnya kebudayaan lokal berdampak pada hilangnya pegangan nilai dan orientasi suatu masyarakat. Konflik identitas yang terjadi di Maluku tahun 1999 merupakan salah satu contoh permasalahan sosial akibat memudarnya kesadaran atas kearifan lokal. Artikel ini mendiskusikan kearifan lokal dalam tradisi Pela Gandong di Maluku Tengah, mengenai muatan nilai yang terkandung dalam tradisi Pela Gandong, perkembangannya secara sosio-historis, dan relevansinya bagi konteks kehidupan masyarakat Maluku Tengah kontemporer. Peneliti berusaha menjawab pertanyaan tersebut menggunakan kajian Axiologi dan Filsafat Kebudayaan. Penelitian ini merupakan penelitian kepustakaan dengan mengacu pada sumber kepustakaan ilmu antropologi dan sejarah untuk mendeskripsikan tradisi Pela Gandong. Artikel ini mencakup tiga bagian: bagian pertama berusaha mengurai konteks sosio-kultural masyarakat Maluku Tengah serta konteks konflik identitas dan resolusinya di mana nilai-nilai luhur dalam tradisi Pela Gandong menjadi inspirasi terwujudnya perdamaian. Bagian kedua meninjau Pela Gandong dari objek formal filsafat nilai. Hasil analisis ditemukan bahwa dimensi nilai yang dominan dalam tradisi Pela Gandong adalah nilai spiritual dan nilai vital. Bagian terakhir yakni urgensi adanya kontekstualisasi dan revitalisasi gagasan Pela Gandong sebagai oease nilai sekaligus cara pandang bagi praktik kehidupan masyarakat Maluku.
\end{abstract}

Kata Kunci: Filsafat; Nilai Tradisi; Pela Gandong; Maluku

\begin{abstract}
Indonesia is multicultural country. Local genius are existed in each region and it's local cultures. Traditional culture seems eroded. The impact of losing local values and orientation might cause social problems. Religious identity conflict happened in 1999 is an example of social problems that need to be deal. This article discusses local genius and the core value of Pela Gandong tradition in central Maluku. What are the values contained in the Pela Gandong tradition and how is the socio-historical background? What is the relevance of Pela Gandong's values for the social context of contemporary Maluku. The author tries to answer these questions using the philosophy of values and cultural philosophy perspectives. This writing refers to bibliographical research concerning the literary sources of cultural and historical anthropology that describe the Pela Gandong tradition. This article includes three parts: the first part attempts to analyze the socio-cultural context of the people of Central Maluku. The context of the people of Central Maluku which was hit by an identity conflict in 1999. Conflict resolution and peace inspired by the noble values in the Pela Gandong tradition. The second part reviews Pela Gandong from the perspective of Axiology. The core values that play the core hierarchy of values in this tradition are spiritual and vital value. The last part is the description and the urgency of contextualization of Pela Gandong's conception as a guiding value as well as the worldview forming the everyday practice of the Moluccan people.
\end{abstract}

Keywords: Philosophy; Value; Tradition; Pela Gandong; Maluku

\section{PENDAHULUAN}

Indonesia negara yang kaya akan budaya. Keadaan ragam budaya membuat Indonesia dikenal memiliki masyarakat multikultural sampai hari ini. Era globalisasi dan hiper-koneksi dewasa ini berdampak bagi kebudayaan yang telah hidup lama. Rasa penghormatan dan bangga terhadap warisan budaya serta adat merupakan sikap yang perlu diutamakan. Terkhusus dalam kondisi kebudayaan dan kearifan lokal mulai memudar dari ingatan, kesadaran dan praktik hidup masyarakat lokal (Bin Tahir, 2019). Fenomena sosial kontemporer menunjukkan gejala-gejala tergerusnya tradisi dan budaya lokal nusantara yang sejatinya adalah kekayaan bangsa. Modernisme 
dan industrialisasi mendominasi dan menjadi cara pandang tunggal dalam memahami kehidupan. Masyarakat yang kehilangan modal kultural berkemungkinan besar dihantam gelombang dan arus dominasi industri yang kapitalistik. Kebudayaan nusantara sebagai paradigma dan praktik hidup masyarakat perlahan tergantikan oleh budaya kapitalisme dan pasar bebas. Keadaan yang tidak perlu terjadi jika semua elemen bangsa mengingat cara untuk berdaulat. Bangsa besar adalah bangsa yang memegang budayanya dengan teguh kemudian berselancar dalam derasnya arus perubahan dan tantangan zaman.

Budaya nasional sebagai puncak-puncak kebudayaan lokal merupakan fondasi sosial kehidupan bangsa. Kerapuhan ikatan sosial antar masyarakat menjadi sinyalemen bahwa budaya nusantara perlu direvitalisasi, digali, ditafsirkan kembali secara konstruktif. Ketahanan masyarakat dalam konteks negara dan bangsa tergantung dari seberapa besar kesungguhan mempraktikkan puncak-puncak kearifan lokal yang tersebar di nusantara. Kearifan lokal menjadi unsur pembentuk norma dan nilai bagi kehidupan berbangsa. Kearifan lokal sebagai isi sekaligus tujuan suatu masyarakat menentukan proses majunya suatu masyarakat. Memahami kearifan lokal berarti sekaligus memahami kebudayaan dimana kearifan tersebut muncul (Uge, 2019:383). Bangsa Indonesia dibangun di atas nilai-nilai budaya dan kearifan yang ada. Nilai dan kearifan budaya tersebut menjadi unsur dan bahan bagi perumusan falsafah bangsa dan dasar negara. Nilai hidup masyarakat nusantara diabstraksikan secara abstrak, umum, universal dan dijadikan kompas bagi gerak kehidupan bangsa. Cita cita dan arah pembangunan nasional secara legal termuat dalam UUD 1945. Tuntunan etis bagi praktik kehidupan berbangsa didasarkan oleh nilai-nilai kesosialan dan moralitas kebangsaan.

Konflik bercorak agama pernah terjadi di Maluku tahun 1999 bertentangan dengan landasan nilai bernegara dan berbangsa. Norma dasar kehidupan berbangsa dilandaskan atas rasa persatuan dan kemanusiaan. Berketuhanan tidak lantas menegasi rasa kemanusiaan dan keadilan secara luas (Soeprapto, 1995). Kesatuan dan keutuhan dalam sila ketiga datang dari kearifan dan keadaban masyarakat di nusantara. Persatuan dan kesatuan yang otentik bangsa Indonesia bersumber dari lokus budaya nusantara. Kebudayaan lokal merupakan unsur kebudayaaan nasional. Untuk itu Pela Gandong merupakan salah satu kebudayaan nusantara yang memiliki urgensi untuk dipahami lewat kajian ilmu-ilmu dan kemudian direvitalisasi. Pengkajian tentang muatan nilai Pela dan Gandong penting dalam kerangka menemukan kebudayaan dan nilai-nilai kearifannya. Salah satunya dengan merefleksikan salah satu wujud kebudayaan nusantara dari masyarakat Maluku. Kebudayaan nusantara dari Maluku Tengah yakni Pela Gandong dapat berfungsi menjadi oase inspirasi dan sumber nilai-nilai hidup berbangsa dan berbudaya.

Kajian filsufis ini dihasilkan lewat metode penelitian kepustakaan. Artinya, dalam upaya mendeskripsikan suatu karya budaya penelitian dilakukan dengan Analisa dan refleksi filsafati yang secara metodologis merupakan penelitian kualitatif. Upaya dari kajian ini adalah untuk menemukan sistem nilai pada kebudayaan Maluku, yakni Pela Gandong. Masalah yang hendak diketahui dalam penelitian tentang tradisi Pela Gandong antara lain; Pertama, apa saja nilai yang terkandung dalam tradisi Pela Gandong? Bagaimana perkembangannya secara sosio-historis? Kedua, apa relevansi dari muatan nilai-nilai Pela Gandong terhadap konteks masyarakat Maluku Tengah kontemporer. Penulis berusaha menjawab pertanyaan tersebut menggunakan perspektif Filsafat Nilai atau axiologi dan Filsafat Kebudayaan. Wujud kebudayaan dalam keilmuan sosial humaniora secara umum dilihat wujudnya berupa benda-benda, praktik keseharian, norma, hukum, nilai, gagasan konsep, serta pandangan dunia (worldview). Dengan keluasan tersebut maka kebudayaan bersifat abstrak dan konkret. Kebudayaan adalah sistem kepercayaan dan praktik atasnya. Kebudayaan dihasilkan dari kompleksitas aktivitas manusia dalam interaksinya secara sosial. Interaksi komplek tersebut menghasilkan sistem sosial. Sistem budaya dan sistem sosial dihasilkan dari nilai-nilai yang dipercayai dan sekaligus menghasilkan nilai-nilai secara dinamis. Pela Gandong sebagai satu buah kearifan budaya hendak dipahami secara ekstensif dan intensif dalam penelitian ini. Tujuannya untuk menemukan hakikat nilai dalam Pela Gandong. Hakikat nilai-nilai yang dipercayai merupakan dasar filsofis suatu kebudayaan masyarakat. Pela Gandong merupakan kepercayaan, pengetahuan dan dasar filsufis masyarakat Maluku Tengah. 


\section{METODE}

Penulisan artikel ini menggunakan studi literatur, yakni menelusuri berbagai literatur yang tersedia, baik itu berupa buku, jurnal, artikel dan laporan penelitian yang berkaitan dengan Filsafat Nilai sebagai objek formal dan muatan nilai dari tradisi Pela Gandong sebagai objek material. Penelitian ini lakukan dengan langkah-langkah runtut yakni dimulai dengan langkah pertama, yakni inventarisasi. Langkah ini berupa kegiatan mengumpulkan sebanyak mungkin data kepustakaan dan karya yang berkaitan dengan sejarah dan kebudayaan tradisi Pela Gandong. Setelah terkumpul, maka dilakukan langkah kedua yakni identifikasi dan klasifikasi. Artinya bahwa bahan yang telah dikumpulkan diidentifikasi dan dilakukan pemilahan agar dapat dipetakan antara data primer dan sekunder. Setelah klasifikasi dan pemilahan dilakukan maka dilanjutkan dengan langkah ketiga, yakni analisis data. Analisis dilakukan atas data primer dan sekunder hasil dari pemilahan tahap sebelumnya. Analisis dilakukan secara kritis dengan menggunakan unsur metodis yang berlaku.

Metode yang diterapkan dalam menganalisis data primer dan sekunder yang pertama adalah interpretasi. Metode interpretasi dilakukan atas data yang telah terkumpul, khususnya terkait aspek filsofis, antropologis dan historis dari tradisi Pela Gandong di Maluku Tengah. Intepretasi dilakukan sampai tahapan diperolehnya suatu pemahaman yang cukup dalam estimasi peneliti. Setelah hasil intepretasi didapat maka dilanjutkan pengkajian dengan metode holistik. Metode ini dipakai untuk mencari pemahaman yang menyeluruh dan mendalam tentang muatan nilai dalam tradisi Pela Gandong. Unsur metodis yang terakhir yang dipakai dipakai dalam proses analisa adalah metode Heuristik. Analisis yang dilakukan dengan metode ini adalah analisis filsafati untuk menemukan suatu pemahaman tentang dimensi dan hirarki nilai yang signifikan dalam tradisi Pela Gandong. Hasil tersebut kemudian direfleksikan secara kritis-etis untuk menemukan relevansi dan aktualisasinya bagi kehidupan masyarakat Maluku Tengah kontemporer.

\section{HASIL DAN PEMBAHASAN}

\subsection{Tantangan kontemporer dan Urgensi Revitalisasi Budaya Pela Gandong}

Kompleksitas persoalan yang dialami bangsa Indonesia merupakan akibat sistem penegakan hukum dan kebijakan publik yang buruk. Persoalan dalam tataran paradigmatik melahirkan masalah turunan yang pelik dan kompleks. Adab politik yang rendah, sistem pemerintahan yang lemah dan koruptif mengakibatkan stagnasi pembangunan di level lokal. Marjinalisasi terjadi di berbagai daerah mengakibatkan ketidakmerataan pembangunan di seluruh pelosok wilayah negara. Terdapat disparitas tinggi bidang sosial-ekonomi. Selain itu kompetisi dan dominasi ekonomi yang tidak sehat ikut merusak kesatuan organik antar kelompok komunitas. Dampak buruk dari keadaan tersebut otomatis melemahkan integrasi sosio-kultural.

Ketahanan bangsa tergantung dari seberapa besar kesungguhan mempraktikkan puncakpuncak kearifan lokal yang tersebar di nusantara. Bangsa Indonesia dibangun dari nilai budaya dan kearifan yang ada di nusantara. Nilai budaya dan kearifan tersebut menjadi unsur dan bahan bagi perumusan falsafah bangsa. Nilai hidup masyarakat nusantara diabstraksikan sehingga berfungsi sebagai kompas bagi jalannya kehidupan bangsa. Cita cita dan arah pembangunan nasional secara legal termuat sistem hukum yang bersifat hirarkis yang mengatur kehidupan masyarakat dari tingkat pemerintah pusat sampai unit-unit kecil di tiap desa di Indonesia. Kewajiban etis bagi praktik kehidupan berbangsa didasarkan oleh nilai-nilai kesosialan dan moralitas kebangsaan.

Wawasan nusantara dan integrasi sosial-budaya semakin hari semakin pudar bahkan setelah bangsa Indonesia mampu keluar dari rezim otoriter. Era yang dikenal dengan nama reformasi, dengan kata lain perubahan forma dari kekuasaan negara yang ditandai dengan runtuhnya Orde Baru. Reformasi hanya membuka ruang pluralitas budaya tetapi belum memberi kerangka kerja budaya. Dampaknya belum tampak perbaikan nasib budaya bangsa yang wujudnya adalah budayabudaya daerah. Pasca reformasi bermunculan konflik-konfik horizontal, gerakan-gerakan berdasarkan chauvinisme dan fundamentalisme agama yang ekstrim. Reformasi membuka ruang demokrasi bagi seluruh elemen bangsa tapi belum ada praktik sosial yang etis dan dasar hukum yang kuat. Gerak kepentingan dalam ruang demokrasi bias kepentingan kelompok oleh karenanya justru membahayakan kesatuan bangsa. Muncul fanatisme golongan, kelompok, etnisitas, serta agama dijadikan komoditas meraih kekuatan politik. Akibatnya banyak terjadi kasus intoleransi. 
Konflik yang bercorak agama yang pernah terjadi di Maluku bertentangan dengan landasan nilai bernegara dan berbangsa. Berketuhanan tidak lantas menegasi rasa kemanusiaan dan keadilan secara luas. Kesatuan dan keutuhan dalam sila ketiga datang dari kearifan dan keadaban masyarakat di nusantara. Persatuan dan kesatuan yang otentik bangsa Indonesia bersumber dari nilai yang hidup lokus budaya nusantara. Kebudayaan lokal merupakan causa material kebudayaaan nasional. Pela Gandong merupakan salah satu kebudayaan nusantara yang membutuhkan revitalisasi dan perhatian. Pengkajian atas Pela penting dilakukan untuk memahami kembali nilai-nilai kearifan yang ada. Pela merupakan wujud kearifan lokal salah satu kebudayaan nusantara di masyarakat Maluku Tengah. Pela Gandong dapat berfungsi menjadi oase inspirasi dan sumber nilai-nilai hidup berbangsa dan berbudaya. Pela Gandong sebagai suatu wujud kebudayaan merupakan warisan leluhur memiliki nilai-nilai yang sangat fundamental. Pela Gandong memuat nilai-nilai kesosialan dan moral sekaligus. Wujud paling nyata dari nilai sosial dan moral adalah sikap gotong royong dan persaudaraan.

Secara historis wujud konkret dari nilai-nilai sosial dan moral yang berasal dari kebudayaan masyarakat Maluku sempat tercoreng akibat konflik sosial bercorak sekterian yang memakan korban ribuan korban nyawa terjadi sekitar tahun 1999-2002 (Tangidy, 2016). Konflik ini mengakibatkan kerugian besar di bidang sosial dan ekonomi serta meninggalkan luka dalam ingatan kolektif. Sebagian besar masyarakat pasca konflik hidup dalam trauma. Konflik dengan skala relatif kecil setelahnya masih sering terjadi setelah tahun 2002 pasca perjanjian Malino II. Konsekuensinya dari keretakan sosial dan budaya tersebut berdampak pada stabilitas ekonomi, politik dan sosial di daerah Maluku saat itu. Ditambah lagi secara sosio-demografis muncul segregasi wilayah berdasarkan agama. Kondisi konflik yang terjadi dalam skala lokal di Maluku saat itu sangat berdampak pada stabilitas nasional. Konflik bernuansa agama yang terjadi di Maluku merusak integrasi sosial dan budaya bangsa. Kerugian besar dialami masyarakat bangsa Indonesia terkhusus masyarakat Maluku Pasca Reformasi. Konflik horizontal berdarah menghasilkan korban luka, nyawa, serta harta benda. Infrastruktur ekonomi, sosial, dan pendidikan masa itu dalam status sekarat. Nilainilai kemanusiaan hampir tidak bermakna. Cita-cita kehidupan berbangsa dalam konteks lokal tertutup kabut gelap konflik horizontal tersebut. Masyarakat Maluku harus bertahan hidup dalam nihilitas harapan atas peran Negara. Kekacauan (chaos) tersebut mendesak tiap kelompok untuk bertahan. Logika bertahan hidup (logic of survival) yang ekstrim adalah satu-satunya modus utama bagi sebagian besar masyarakat Maluku di masa konflik.

Kondisi konflik dan perpecahan menjauhkan praktik hidup berdasarkan cita-cita bersama. Konflik menjauhkan masyarakat dari kehidupan bangsa yang sejahtera, berkeadilan dan bermartabat kemanusian. Konflik sebagai buah praktik hidup berbangsa yang terdegradasi menjauhkan masyarakat dari nilai-nilai kemanusiaan universal. Kehidupan bangsa yang banal tidak menampakkan nilai-nilai kebersamaan, keadilan, dan kesejahteraan. Era Reformasi yang seharusnya menjadi ruang hidup bagi optimisme baru dalam perjalanannya diuji oleh banyak permasalahan yang tidak selesai di masa lalu dan terus bermunculan sampai hari ini. Pasca reformasi dan otonominasi sistem pemerintahan memunculkan banyak sekali penguasa-penguasa kecil di daerahdaerah. Pusat kekuasaan tidak tersentral di Jakarta seperti di zaman orde baru akan tetapi di sisi lain muncul aktor dan kepentingan politik yang skalanya bersifat lokal. Kompetisi perebutan kekuasaan lokal yang menjadi kompetisi kursi-kursi pemerintahan mewarnai keadaan politik dan ekonomi di Maluku. Kompetisi yang tidak sehat menghasilkan praktik korupsi mengorbankan kepentingan pembangunan. Muncul wacana yang tebal bahwa terjadi perebutan kekuasaan lokal serta juga keterlibatan militer yang menjadi hambatan resolusi konflik di Maluku.

Selain konflik Maluku terdapat beberapa konflik lain yang terjadi di Indonesia antara lain Sampit, Papua, Poso, Aceh, dan Ambon. Konflik yang terjadi merusak citra bangsa dan bertentangan nilai-nilai falsafah bangsa. Masalah kemanusiaan tersebut jika dilacak akarnya muncul akibat adanya degradasi pada jantung sumber nilai masyarakat. Kebudayaan daerah sebagai sumber nilai masyarakat semakin pudar seiring berjalannya waktu. Kebudayaan Maluku adalah salah satu contohnya. Kurang diperhatikannya urgensi dari kearifan budaya Maluku dapat dikakatan adalah akiba dominasi kompetisi ekonomi, industrialisme dan kapitalisme yang merasuki tata pengaturan hidup berbangsa. Pembangunan dan ketahanan sosial berbasis budaya lokal cenderung tidak berdaya dihantam arus budaya kapitalisme, industrialism yang memiliki nilai-nilai sendiri. Hal 
tersebut diperparah oleh kompetisi antara elit dalam merebut dominasi politik ekonomi. Dalam kondisi tersebut sering muncul politik pecah belah (devide et impera) yang sering membuat masyarakat terbelah berdesarkan identitas.

\subsection{Paradigma Nilai dalam Dinamika Budaya}

Kondisi dan masalah multidimensi yang dialami Indonesia secara umum, secara khusus masyarakat Maluku sebagai bagian dari bangsa Indonesia perlu dicarikan solusi paradigmatiknya. Jalan untuk menemukan pandangan dan tawaran gagasan nilai membutuhkan kajian atas dimensi historis dan kultural dari budaya itu sendiri. Memahami budaya dalam lintasan sejarah dapat dimulai dengan menimbang kembali gagasan Arnold Toynbee dalam A Study of History (1961). Menurutnya, kebudayaan akan berkembang apabila terdapat suatu keseimbangan antara Challenge dan Response (Bakker, 1984). Apabila yang ditemui dalam satu kebudayaan proporsi challenge lebih besar dibandingkan response maka kebudayaan tersebut cenderung tergerus dan punah. Sebaliknya kebudayaan cenderung mengalami stagnasi apabila proporsi challenge lebih kecil dibanding response. Akibatnya kebudayaan tidak berkembang dinamis karena bersifat hegemonik dan dominatif. Dalam kondisi tersebut kemungkinan kemungkinan yang biasanya terjadi adalah suatu masyarakat dan kebudayaannya berkembang sampai di titik jenuh lalu menghilang. Memakai sudut pandang tersebut melihat fenomena dan masalah masyarakat Maluku membawa pemahaman bahwa secara sederhana terdapat banyak challenge namun tampak ketiadaan response. Tidak tampak reaksi dan ekspresi kebudayaan lokal yang muncul tindakan mengatasi masalah di awal-awal konflik horizontal tahun 1999-2002. Sebagian besar masyarakat terjerat masuk ke dalam konflik komunal yang tidak berdasar secara sosial, kultural dan moral.

Tradisi yang penting dalam kehidupan masyarakat Maluku Tengah secara historis dan kultural adalah Pela Gandong. Tradisi Pela-Gandong pada hakikatnya merupakan hasil dan buah dari proses interaksi sosial masyarakat di kepulauan sekitar Maluku Tengah. Dengan bahasa yang lebih fenomenologis Pela Gandong merupakan buah perjumpaan antar kelompok manusia dalam dunianya. Dunia yang dimaksud adalah dunia yang hari ini dikenal secara geografis dan administratif sebagai Maluku. Pela Gandong merupakan buah kehidupan masyarakat Maluku yang berbudaya. Hakikat manusia adalah makhluk berbudaya. Budaya merupakan bagian dan buah dari relasi manusia dan dunia. Van Peursen (1988) seorang filsuf kebudayaan menyatakan bahwa budaya merupakan endapan dari kegiatan dan karya manusia. Inti dan pokok kebudayaan tidak terletak pada benda-benda atau apapun yang ada di depan manusia. Pokok kebudayaan merupakan satu fenomena sebagai sesuatu yang dinamis dan berproses. Kebudayaan merupakan segala upaya manusia dalam memandang, memaknai, menembus alam kebendaan menuju proyeksi dan arah tujuan tertentu. Untuk itu orientasi merupakan keniscayaan penyempurnaan eksistensi manusia (Peursen, 2003). Kebudayaan bagi Van Peursen dimengerti sebagai kata kerja. Itu berarti kebudayaan mengandaikan proses dan kelangsungan eksistensi hidup, eksistensi manusia secara sosial. Kebudayaan menyangkut dimensi historisitas, proyeksi, kerjasama sosial. Kelangsungan kebudayaan menyangkut sosialitas manusia dalam tata relasi dan sistem hidup satu masyarakat.

Kebudayaan dan kelangsungan eksistensi tidak dapat dipisahkan dari apa yang disebut nilai. Nilai sebagai suatu yang abstrak merupakan wujud dari dimensi spiritual manusia yang berakal budi dan memiliki suara hati. Hasil abstraksi tentang nilai yang muncul lewat makna melekat pada faktafakta sosial dalam eksistensi manusia. Sejalan dengan pandangan nilai C A Van Peursen (1990) bahwa nilai selalu merupakan akar dari fakta. Baginya Fakta tidak mendahalui nilai. Kehidupan sehari-hari (everydayness) satu masyarakat dikondisikan oleh nilai-nilai yang dipakai dan dipercayai oleh masyarakat tersebut. Corak masyarakat dan praktik kebudayaannya selalu melekat dengan lokus realitas sosialnya. Nilai-nilai yang hidup di masyarakat hanya dapat dipahami dan dimengerti dalam eksistensi dan sosialitas dalam kehidupaan riil.

Notonegoro (1995) menjelaskan bahwa nilai dapat dikategorikan berdasarkan tiga fungsinya. Pertama, nilai material merupakan sesuatu yang berguna bagi kehidupan jasmani manusia. Kedua, nilai vital sebagai sesuatu dasar untuk mengadakan aktivitas atau kegiatan dalam hidup manusia. Ketiga, nilai kerohanian sebagai sesuatu yang bersifat spiritual menyangkut kebenaran, keindahan, kebaikan, religiusitas. Nilai (value) merupakan suatu kualitas yang dipercayai 
dan berfungsi mengisi kebutuhan manusia. Nilai pada hakikatnya adalah sifat dan kualitas yang melekat pada manusia dan dunianya. Nilai merupakan suatu kenyataan yang tersembunyi dibalik yang tampak secara inderawi. Nilai merupakan sesuatu yang apriori. Oleh sebab itu tidak dibutuhkan pengalaman inderawi tentangnya terlebih dahulu untuk mengerti adanya nilai dalam satu masyarakat. Nilai bersifat abstrak dan immaterial.

Kegiatan mendalami dan memaknai budaya idealnya sampai pada tahapan menemukan nilai-nilai filsufis yang terkandung di dalamnya. Van Peursen (1990) menegaskan bahwa setiap kebudayaan memiliki nilai-nilai di dalamnya. Nilai benar-benar ada (Alfariz, 2020). Kenyataan tentang nilai bukanlah kenyataan yang eksplisit. Nilai sebagai realitas tersembunyi di balik kenyataan empiris, yang tampak dan langsung mengemuka. Walaupun tersembunyi di balik kenyataan lain, tidak sama sekali tergantung pada kenyataan-kenyataan tersebut. Nilai bersifat mutlak dan tidak berubah. Nilai tidak akan terpengaruh oleh perubahan yang terjadi pada objek dan kenyataan lain yang mengkonstitusikannya (Alfariz, 2020). Nilai-nilai merupakan wujud dan hasil dari aktivitas dan perilaku yang khas dan unik manusia dalam kebudayaan tersebut. Pendapat senada tentang nilai dalam kehidupan budaya dilihat dalam pemikiran Risieri Frondizi. Dia menyebutkan bahwa salah satu ciri khas yang hakiki dari nilai adalah penampakannya dalam urutan yang hierarkis (2001). Nilai dalam rumusannya bersifat hierarkis. Dalam pengkategoriannya terdapat nilai yang lebih tinggi dan ada nilai yang lebih rendah. Catatan yang perlu dipahami dalam melihat konteks kebudayaan adalah bahwa hirarki nilai ini tidak saklek. Pada konteks yang partikular, klasifikasi dan tata urut secara spesifik bisa saja berbeda.

Nilai yang terkandung dalam Pela Gandong jika dilihat dari pandangan tersebut merupakan buah dari sosialitas dan kehidupan masyarakat Maluku. Makna dari nilai-nilai dalam Pela Gandong dalam perspektif Axiologi Max Scheler berada pada taraf nilai Vital. Nilai vital dan spiritual berarti nilai yang tidak tergantung dan tidak dapat direduksi menjadi hanya persoalan kenikmatan (Wahana, 2008). Suatu nilai dapat berada lebih tinggi dari nilai lain ketika nilai tersebut menjadi dasar bagi nilai yang lain itu. Nilai Vital dalam kehidupan masyarakat Maluku muncul dalam interaksi dan sosialitasnya untuk proyeksi untuk menghadapi tantangan yang dinamis. Pela Gandong juga dapat diposisikan ada pada taraf nilai spiritual sebab menyangkut sesuatu yang suci. Ikatan sosial yang dijalin dalam Pela Gandong mengandaikan intuisi kepada yang spiritual, tinggi, suci, suatu yang absolut. Atas dasar itulah ikatan Pela tidak pudar dan tergerus oleh ruang dan waktu.

Nilai spiritual menjadi dasar penting karena dalam kehidupan masyarakat Maluku tengah mayoritas menganut dua agama yakni Islam dan Kristen. Konsekuensinya nilai spiritual dalam dala komunitas kelompok yang memiliki keyakinan religi prinsip spiritualitas menjadi landasan. Setiap perjumpaan ikatan Pela dan Gandong mengandaikan landasan-landasan spiritual. Masyarakat antara negeri dengan sadar membangun rasa toleran yang sangat tinggi karena ikatan Pela Gandong merupakan sumpah dan perjanjian yang sungguh-sungguh. Perjanjian tersebut lantas ditaati. Dalam kehidupan masyarakat yang diikat Pela tidak terdapat sedikitpun permasalahan dalam kehidupan bersama. Nilai yang terdapat dalam tradisi Pela Gandong terwujud dalam pemaknaan sosialitas masyarakat Maluku Tengah. Wujudnya tampak dalam praktik yang memuat prinsip-prinsip kegotongroyongan, kebersamaan, kesadaran untuk saling membantu. Sampai sekarang tradisi ini terus ada upaya agar tradisi dilestarikan dan diwariskan demi kehidupan masyarakat di Maluku Tengah.

\subsection{Kebudayaan Sebagai Oease Nilai}

Pengkajian atas kebudayaan merupakan tugas ilmu sosial dan humaniora. Kajian atas budaya dan nilainya perlu dilakukan sebab kebudayaan adalah suatu entitas buah dari proses manusia mendunia. Pemahaman manusia dan dimensi-dimensinya tidak dapat dilakukan selain dengan cara memahami konteks kebudayaannya. Kebudayaan patut dikaji demi perkembangan masyarakat dalam kebudayaan itu sendiri. Kebudayaan bersifat bersifat dinamis. Kebudayaan adalah sesuatu yang seyogianya terbuka atas kritik sebab ia memang berkembang sesuai zaman dan kebutuhan hidup manusia dan sekelilingnya (Asmarani, 2020). Kebudayaan menurut Edward Burent Taylor adalah keseluruhan kompleks kehidupan masyarakat. Kebudayaan sebagai keseluruhan yang kompleks meliputi pengetahuan, kepercayaan. Kesenian, hukum, moral, kebiasaan, kecakapan, dan 
kebiasaan yang diperoleh manusia sebagai anggota masyarakat. Kebudayaan menyangkut keberadaban manusia. Kebudayaan selalu berkaitan dengan tradisi dan adat sehingga kajian tentang budaya harus menyinggung kedua hal tersebut. Koentjaraningrat (2004) menjelaskan bahwa adat adalah wujud ideal dari kebudayaan. Wujud ideal itu disebut "adat-tata kelakuan”, sebab adat berfungsi mengatur tata kelakuan.

Filsafat melihat kebudayaan pada ranah ontologis yang merujuk pada penempatan nilai sebagai aspek formal, substansial yang inheren dan melekat (embedded). Filsafat sebagai objek formal melihat kebudayaan pada tataran ontologis dengan makdsud untuk menemukan inti, jiwa, dan hakikat kebudayaan. Hakikat yang dimaksud adalah pokok substansial yang mengarah pada totalitas kehidupan manusia. Inti dari kebudayaan sendirinya terdapat pada eksistensi. Dengan kata lain terdapat dalam bagaimana cara manusia mendunia dengan corak yang paling manusiawi. Wujud yang khas dari cara mendunia manusia adalah kemampuan berdaya pikir, cipta dalam proses perkembangan budaya secara dinamis. Pada tataran nilai secara normatif perkembangan dan kemajuan budaya ditandai dengan pengutamaan harkat dan martabat manusia.

Ikatan Pela Gandong mencerminkan penghormatan sosial dan rasa kemanusiaan. Pela Gandong mencerminkan nilai sosial, persaudaraan dan kekeluargaan dalam budaya Maluku. Kehidupan sosial masyarakat Maluku dilandaskan pada nilai dan perjanjian luhur yang menjadi imperatif yang mengatur interaksi secara sosial. Secara filosofis dasarnya adalah bahwa manusia secara esensial memiliki dimensi sosial. Kesosialan manusia merupakan sesuatu yang eksistensial, Artinya bahwa keberadaan manusia tergantung pada relasi dengan sesama (Snijders, 2004). Tradisi Pela Gandong merupakan buah dari keadaan eksistensial masyarakat Maluku Tengah. Pela Gandong dari sudut pandang filsafat merupakan kemampuan bekerja sama untuk menghasilkan satu sistem sosial dan budaya. Pela Gandong dapat disebut sebagai kemampuan kerja-sama masyarakat Maluku tengah. Secara prakmatik manusia memang memiliki kemampuan untuk dapat bekerjasama demi menghasilkan kehidupan bersama kemasyarakatan (Dewey, 1998). Masyarakat Maluku Tengah secara mendasar merupakan kumpulan individu yang mengemban dan menampilkan nilai-nilai sosial yang khas masyarakatnya.

\subsection{Sejarah Tradisi Pela}

Pelacakan geneologi nilai-nilai dalam tradisi Pela Gandong dilakukan dengan jalan pengkajian historis. Sejarah sebagai sebuah kajian perlu diakui merupakan sebuah narasi yang disusun sedemikian rupa berdasarkan unsur-unsur yang menandai suatu masa lalu. Sejarah merupakan rekonstruksi masa lalu (Akhyat, 2019). Sebagai narasi sejarah tradisi Pela Gandong merupakan rekonstruksi yang bersifat koheren. Narasi sejarah tradisi Pela Gandong beserta konteks komprehensif masyarakat Maluku Tengah dibahas dalam karya sejarawan budaya Dieter Bartels berjudul "Di Bawah Naungan Gunung Nunusaku Dieter Bartels" (2018). Karya tersebut memuat narasi tradisi Pela Gandong yang dimulai sekitar Abad 14-15. Pada abad-abad tersebut terjadi banyak perang antara klan-klan di Nunusaku yang menjadi pusat kehidupan masyarakat Maluku saat itu. Nunusaku sendiri merupakan nama gunung di Pulau Seram yang dipakai sebagai penyebutan mewakili kehidupan sosial kelompok-kelompok masyarakat sekitar.

Budaya Pela secara kultural dan historis merupakan warisan masyarakat di Maluku Tengah. Penduduk awal yang mendiami pulau seram dikenal dengan nama Alifuru. Alif dan Uru yang artinya manusia pertama. Pengkajian historis atas masyarakat alifuru dilakukan para ahli untuk menemukan semacam landasan dalam memahami tradisi Pela. Dieter Bartels salah satu ilmuan sejarah dan budaya Maluku terbesar menyebutkan bahwa Pela berakar dalam tradisi mengayau atau tradisi berburu kepala. Tradisi mengayau ini dilakukan kampung-kampung dan klan-klan di Maluku aktif saat melakukan penyerangan. Untuk melakukan pertahanan dari klan-klan yang lebih kuat ikatan Pela diadakan. Pela terkadang diadakan untuk kepentingan pertahanan, ataupun persetujuan damai setelah pertikaian (Bartels, 2018). Seiring berjalan waktu tradisi ini mengalami perubahan. Menurut catatan orang eropa awal sampai paruh pertama abad 17 Pela bersifat permanen. Fungsi Pela awal hanya seputar perjanjian perang dan damai lambat laun termuat alasan ekonomi di dalamnya.

Manusia awal-awal di Maluku yang dapat dilacak oleh ilmu sejarah dan budaya terbagi atas dua klan besar yakni klan siwa dan klan lima. Perang yang terjadi didamaikan oleh ikrar dan janji 
Pela. Menurut Dieter Bartels (2018), Pela pada awalnya digunakan untuk perjanjian damai setelah perang. Pela lambat laun berfungsi sebagai ikatakan persekutuan antara beberapa negeri, sebagian negeri jauh dan beda agama. Dengan itu, Pela juga menyentuh dimensi ekonomi. Pela kemudian berguna bagi kebetuhan kelangsungan masyarakat secara ekonomis dan hal tersebut bersifat inheren dalam ikatan Pela (Bartels, 2018). Pela dipahami sebagai suatu persaudaraan antara orangorang negeri yang tidak dapat diganggugugat. Klan Siwa atau secara kultural disebut Patasiwa dan klan lima atau Patalima adalah dua kelompok yang mendasari struktur masyarakat adat Maluku Tengah serta tradisi Pela itu sendiri. Konflik serta pengelolaan konflik antar masyarakat dari klanklan tersebut melahirkan tradisi dan ikrar Pela.

\section{Kuru Siwa Rima \\ Kuru Siwa Rima \\ Tutu ya hei lete hei lete oo \\ Hei lete Nunusaku 0, Nunusaku o \\ Nunusaku karu pela, karu pela o \\ Nunusaku sama pela, sama pela o \\ Sama pela wae le telu, wae le telu o, \\ Nunu e, nunu e, nunusaku nunu e, \\ Nunu saku, Nusa Ina, Nunu Siwa Rima o \\ Nunusaku Nusa Ina, Upu Ama Lepa Nia, \\ Tala eti, Sapalewa, Kuru Siwa-Rima e. \\ Upu Ama Karu Pela, Karu pela o.}

Kata Pela jika dilacak makna arti kata ini erat dengan kata sumpah atau perjanjian. Kata Pela muncul dalam nyanyian adat (kapata) di atas dengan judul "Kuru Siwa Rima". Nyanyian kapata tersebut menunjukkan adanya ikrar antara kelompok masyarakat di Maluku Tengah. Ikrar sebagai pegangan masyarakat termuat dalam tradisi Pela Gandong yang diwariskan sejak jaman para leluhur Maluku Tengah. Pela merupakan perjanjian beberapa komunitas. Beberapa kategori Pela berawal dari tanpa relasi. Setelah Pela diadakan relasi sosial praktis berubah. Rasa penghargaan dan perlakuan sosial semakin erat dan penuh penghormatan. Pela menyentuh kesadaran terdalam dan melekat nilai kekerabatan dan komunitas erat (Titaley, 2018). Sebagai teks sejarah kebudayaan pesan dan pokok dari ikrar Pela bersifat imperatif dan wajib dijunjung tinggi. Ikatan Pela, ikatan Gandong mengekspresikan nilai-nilai persaudaraan dan kekeluargaan. Bentuk-bentuk ikatan pela di Maluku dikenal dengan beberapa kategori dasar yakni Pela Tampa Sirih, Pela Gandong, dan Pela Keras.

Pela Tampa Sirih merupakan sistem aliansi antar kampung yang didasarkan pada ikatan persahabatan. Pela Tampa Sirih tidak diikat dengan pengangkatan sumpah. Ikatan Pela jenis ini dilakukan dengan prosesi tukar-menukar tempat sirih dan makan sirih. Pela ini bermakna simbolik. Sirih bermakna dada dan kerangka tulang rusuk manusia. Tembakau menyimbolkan rambut sebagai tempat kedudukan kekuatan hidup manusia. Kapur dan sirih yang jika dikunyah menghasilkan ludah merah melambang darah manusia. Pinang melambangkan keabadian jiwa (Bartels, 2018). Pela ini dikategorikan Pela ringan. Pela jenis biasanya didasari oleh hutang budi, pertolongan yang harus diingat, balas jasa dan suka rela. Jenis pela ini merupakan perjanjian persahabatan. Pada Pela jenis ini perkawinan antar pihak anggota diperbolehkan. Tidak terdapat kewajiban-kewajiban mutlak dalam jenis ini.

Ikatan Pela kedua dinamakan Pela Gandong. Pela ini terkadang disebut Pela rahim. Didasarkan pada ikatan genealogis antara klan-klan kampong sekutu. Ikatan pela ini diformalkan untuk seluruh kampung yang dianggap Pela penuh. Dasar Pela ini adalah pengakuan adanya hubungan adik-kakak. Pela ini sering juga disebut pela bongso yang berarti pakta antara anak bungsu. Kampung yang didiami oleh kakak tertua dianggap memiliki status lebih tinggi dari kampung adiknya (Bartels 2018). Pela Gandong adalah sistem aliansi antar kampong yang didasarkan pada ikrar persahabatan darah (blood brotherhood). Dikarenakan pela ini berdasar terhadap narasi 
persaudaraan darah maka perkawinan antar anggota sangat dilarang keras (Bartels, 2018). Larangan tersebut diinternalisasi dan dipatuhi oleh setiap anggota komunitas ikatan Pela.

Pela Keras merupakan kategori pela yang sesuai namanya merupakan ikatan yang keras. Pela Keras merupakan aliansi yang terbentuk akibat perang. Pela Keras juga berawal dari pertolongan satu terhadap kampung terhadap kampung lain yang mengalami krisis besar. Pakta ini juga sering dikenal dengan istilah Pela Tuni. Pela ini disebut persekutuan asli. Pela Batu Karang merupakan satu sub-kategori dari jenis ketiga ini. Pela Batu Karang kadang juga disebut Pela Perang. Ikatan ini diadakan setelah satu kampung ditolong oleh kelompok lain di saat perang ataupun bencana. Pela Perang kadang disebut Pela Tumpah Darah sebab biasanya terjadi pertengkaran yang menghasilkan pertumpahan darah antara dua kampong (Bartels, 2018). Sumpah Pela ini dilakukan dengan mencampur tuak dengan darah yang diambil dari tubuh pemimpim kedua pihak kemudian diminum oleh kedua pihak tersebut setelah senjata-senjata dan alat-alat perang lain dicelupkan kedalamnya. Alat-alat tersebut nantinya digunakan untuk melawan dan membunuh siapapun yang melanggar perjanjian. Penukaran darah tersebut memeteraikan persaudaraan itu.

Ketiga jenis Pela memiliki satu kesamaan yakni tiap ikatan ada larangan pokok yang disepakati. Larangan pokok wajib dituruti terkadang berwujud norma-norma. Akibat dari pelanggaran ini berupa sanksi dari fungsionaris negeri adat yakni Saniri Negeri. Namun yang lebih sering adalah sanksi yang membawa penyakit, guntur, kilat dan angin ribut dan dianggap sebagai kutukan Tuhan ataupun tete-nene moyang (Malisngongar, 2017). Akibat yang paling sering diingingatkan kepada masyarakat budaya di mana terdapat ikatan pela adalah bahwa pelanggar akan mutlak tidak akan memiliki keturunan. Ganjaran-ganjaran bagi yang melanggar kewajiban pokok biasanya bersifat supranatural sehingga sulit dijelaskan dengan nalar (Hehanusa, 2012).

Hasil tinjauan pustaka atas penelitian ilmu budaya tentang Pela menyebutkan bahwa jenis kategori yang paling kuat dari hubungan antara anggota Pela tidak lain yakni Pela Gandong (Tutuhatumewa, 2010). Hubungan Pela diskaralkan terus-menerus oleh para pewaris. Mekanisme untuk menjaga kelestarian dan mempererat ikatan Pela ini diadakan acara yang disebut Panas Pela. Panas Pela menjadi penegasan atau pembaharuan janji antara dua atau lebih negeri adat (Malisgonggar, 2017). Acara tersebut bermaksud untuk menghangatkan ingatan bersama tentang masa lampau dan sekaligus menjadikan ingatan tentang nilai-nilai dan pokok perjanjian sebagai pegangan hidup ke depan. Panas Pela yang dilakukan secara seremonial. Panas Pela dilakukan berulang kali sesuai kesepakatan anggota satu ikatan pela.

Pela dan Gandong merupakan local genius Maluku yang gagasan pokoknya dapat berguna sebagai pegangan nilai sekaligus cara pandang melihat dunia kehidupan secara luas, secara konkret yakni pelembagaan dan praktek kehidupan masyarakat Maluku. Pela sebagai narasi dan nilai-nilai kehidupan dapat dijadikan titik tolak memahami manusia dan eksistensinya (Ruhulessin, 2019). Pela merupakan buah dari pengalaman historis masyarakat Maluku. Hakikat Pela memilki dimensi etis dan sosial masyarakat Maluku. Implikasi dari fungsi Pela sebagai kewajiban etis dalam hidup sosial orang Maluku adalah ia berguna membangun dan meningkatkan kehidupan masyarakat Maluku secara dinamis dalam rentang eksistensi manusia Maluku di masa lalu, sekarang dan masa mendatang. Sampai hari ini kelompok masyarakat, tokoh adat, akademisi, pelaku seni dan budaya masih menarasikan, melestarikan, serta mengembangkan nilai-nilai tradisi Pela.

Semakin sering muncul narasi dan inisiasi untuk melanjutkan nilai-nilai dasar dalam tradisi Pela Gandong untuk menjaga kehidupan bersama (co-existency) dalam damai serta meningkatkan kohesi sosial masyarakat Maluku terkhusus di pulau Ambon sebagai sentra sosial, budaya, politik dan ekonomi. Pelestarian tradisi Pela Gandong secara praktis berwujud sikap kesetiakawanan, kekerabatan, dan persaudaraan. Melampaui hal tersebut, Maluku pasca konflik membutuhkan dialog, reintegrasi sosial, memelihara perdamaian, dan meningkatkan solidaritas (Elly, 2014; Hasudungan, 2019). Kerja keras, upaya, dan praktik mewujudkan dilandaskan pada falsafah hidup Pela Gandong.

\subsection{Pela Gandong sebagai Falsafah Hidup Orang Maluku}

Kebudayaan pada hakikatnya adalah manisfestasi kehidupan masyarakat dan proses perkembangan. Kebudayaan dalam satu masyarakat lantas menjadi fasfafah sekaligus kepribadian masyarakat itu. Arti budaya sebagai kepribadian adalah bahwa dalam kebudayaan terdapat orientasi 
dan menunjukan karakter, otentisitas, falsafah, dan pandangan dunia. Tradisi beroperasi sebagai medium budaya yang di dalamnya lahir nilai dan makna-makna (Sinnerbrink, 2020). Dalam pandangan hidup tersebut juga tercermin sistem nilai. Kebudayaan juga adalah cara untuk menanggapi dunia. Pandangan dunia dan praktik hidup dapat dilihat dalam perilaku dan keseharian satu masyarakat. Pela sebagai tradisi mencerminkan kepribadian masyarakat Maluku. Pela lahir dari sebuah keingingan untuk mengatasi krisis dan menyelesaikan konflik. Pela merupakan kebudayaan tradisonal yang kemudian mengalami interaksi dengan kebudayaan baru (Islam dan Kristen). Secara substantif akulturasi kebudayaan tersebut tidak melemahkan atau meniadakan Pela (Leirissa dkk, 1982). Pela dalam dinamika dan perkembangannya sebagai kearifan lokal masyarakat Maluku bersifat terbuka. Nilai-nilai yang terkandung dalam ikatan Pela pada level axiologis dapat dikategorikan dalam taraf vital dan spiritual. Artinya nilai-nilai melekat dalam praktik dan kepercayaan masyarakat Maluku. Pela sampai hari ini tetap menjadi pegangan bagi masyarakat Maluku. Pela sebagai tradisi secara substansial mengandung nilai-nilai vital dan spiritual. Secara konkret nilai-nilai tersebut berwujud norma-norma dan kerangka etis Praktik kehidupan.

Pela merupakan produk manusia Maluku. Artinya, masyarakat Maluku merupakan masyarakat berbudaya dan menjunjung tinggi tradisi dan adat. Praktik hidup dituntun oleh sistem nilai yang mengikat kohesi sosial. Secara lebih mendasar Pela merupakan wujud penghargaan atas sesama manusia. Secara fenomenologis kesadaran akan eksistensi diri datang dari kesadaran terhadap adanya yang lain. Ikatan Pela yang terjadi antar negeri-negeri adat di Maluku merupakan hasil kesadaran tentang hakikat manusia sebagai makhluk sosial (social being). Manusia sadar akan dirinya bersama dengan orang lain. Semua realita dari fenomen disadari pasti menghubungkan dirinya dengan yang lain. Semua kesadaran diri adalah kesadaran bersama yang lain (Bakker, 2000). Diri seseorang selalu merupakan bagian dari dunia sekitarnya. Pemahaman seseorang tentang dirinya tergantung pada sosialitasnya.Eksistensi lokalitas manusia dalam tradisi Pela secara mendasar terdapat pada ikatan solidaritas dan persaudaraan. Kebudayaan Pela di Maluku menunjukkan secara fenomenologis bahwa manusia dalam eksistensinya adalah keadaan ada dengan yang lain (being with others). Manusia secara eksistensial merupakan makhluk sosial. Kesosialan sebagai eksostensial dimaksukan bahwa tidak ada aku tanpa relasi dengan sesama (Snijder, 2004). Eksistensi manusia Maluku yang tampak dalam tradisi pela secara historis dan aktual merupakan interaksi sosial-budaya yang organik. Dalam perkembangannya nilai-nilai kesosialian yang mencerminkan hirarki nilai yang termuat dalam tradisi Pela dipraktikkan secara turuntemurun dalam kehidupan budaya masyarakat Maluku.

Pela selain mencerminkan hirarki nilai yakni nilai vital dan spiritual yang berbuah norma dan etika, Pela juga memiliki fungsi pragmatik. Letak nilai pragmatik dari Pela ini adalah untuk mewujudkan kehidupan bersama. Manusia secara umum memiliki kemampuan untuk dapat bekerja sama. Dengan kerja sama manusia membangun masyarakat (Dewey, 1998). Peran Pela ini berfungsi agar kehidupan masyarakat dapat stabil, aman dan berkelangsungan. Tiap individu tentu memiliki kebebasan, kemerdekaaan, kreativitas untuk membentuk jatidiri dan citra diri. Akan tetapi ada dimensi sosial manusia yang juga merupakan hakikatnya. Itu berarti individu hanya dapat mengaktualisasi diri dalam kehidupan sosialnya. Individiu secara mendasar telah menginternalisasi, mengemban dan mengekspresikan nilai-nilai dalam masyarakatnya. Manusia Maluku dalam tradisi Pela menyadari status, kondisi inter-relasional antara dirinya sebagai anggota ikatan sosio-kultural.

Manusia Maluku, dalam bingkai kebudayaan Pela sudah seharusnya memahami dan menghargai keberadaannya sebagai orang bersaudara yang wajib menghargai nilai-nilai sosial kekeluargaan, kemasyarakatan dan kemanusiaan, di mana saja tidak saja ditujukan bagi anggota Pela tetapi secara universal. Pela, dengan demikian merupakan kebudayaan lokal yang bisa menjadi inspirasi bagi penguatan sikap kebangsaan. Pela sebagai kebudayaan Maluku merupakan kearifan lokal dari masyarakat Maluku Tengah berbeda dari kebudayaan daerah lain yang ada di Indonesia namun bersama-sama statusnya sebagai puncak-puncak kebudayaan daerah. Pela dengan demikian merupakan kebudayaan nasional Indonesia. Pela lahir dan terbentuk dari salah satu konteks kehidupan masyarakat di nusantara. Kesatuan politik masyarakat budaya di Indonesia mengerucut menjadi sikap kebangsaan dapat disebut jati diri bangsa. Pela sebagai tradisi dan budaya memuat nilai-nilai persatuan, kekeluargaan, persaudaraan, dan kebersamaan dalam membangun kehidupan 
masyarakat luas. Nilai dan norma sosial tersebut perlu diperhatikan sebagai inspirasi dan aspirasi bagi kehidupan bangsa Indonesia secara menyeluruh. Perbedaan kelompok, etnis, dan agama bukan merupakan hambatan bagi kebhinekaan yang harmonis yang berkemusiaan. Dari sudut pandang filsafat, Pela sebagai paradigma, oease nilai merupakan modal kultural yang berharga dan vital. Prinsip persatuan dalam falsafah Pela secara logis mengandaikan perbedaan. Perwujudan persatuan memerlukan upaya dan inspirasi nilai. Pela secara genealogis merupakan ikrar dari fraksi atau klan yang berbeda. Pela adalah bukti bahwa membangun kebersamaan dan persatuan dalam perbedaan bernilai baik secara etis, sosial, dan benar secara pragmatik.

Harapan tentang Indonesia yang Bersatu, berdaulat, dan sejahtera tidak dimungkin apabila tidak ada rasa penghormatan, rasa kebersamaan melalui upaya menguatkan nilai kerukunan, solidaritas, kerukunan. Kesatuan nasional Indonesia di level lokal dan nasional dapat dicapai lewat perjuangan dalam ranah ekonomi dan politik yang berlandaskan karakter budaya. Pela merupakan salah satu modal budaya. Pela menjadi tawaran gagasan untuk menyuburkan persatuan dan kesatuan serta kesejahteraan kehidupan bersama sebangsa-setanah air.

\section{SIMPULAN}

Setiap bentuk kearifan lokal mengandung nilai-nilai luhur bagi kehidupan manusia di lokus budayanya. Nilai-nilai yang termuat dalam Pela dilihat dari sudut pandang Filsafat Nilai ada pada taraf nilai vital dan nilai kerohanian. Kedua taraf nilai tersebut tampak pada norma-norma dan sistem nilai konkret. Perwujudan nilai yang dapat dilihat dari budaya Pela Gandong yakni, persatuan, solidaritas, kerukunan, kerja sama, gotong royong. Pela sebagai kearifan lokal menghasilkan panduan bagi praktik dan kehidupan sosial yang harmonis. Sejarah dan perkembangan masyarakat Maluku memperlihatkan bahwa konflik dan pertikaian tidak akan membawa kebaikan bagi kehidupan masyarakatnya. Konflik justru mengahasilkan kerugian, penderitaan dan trauma kolektif yang panjang.

Pela Gandong secara aktual menjadi sumber nilai dasar yang membawa masyarakat Maluku keluar dari konflik sekterian. Pela Gandong sebagai tradisi menjadi semacam imperatif untuk mencapai kerukunan dan perdamaian. Pela Gandong dulu hingga sekarang dan bahkan nanti memainkan peran sebagai jatidiri masyarakat lokal setempat dengan demikian tradisi perlu terus dilestarikan sebagai etika sosial masyarakat Maluku. Pela gandong secara normatif berfungsi sebagai inspirasi nilai dan pagar normatif praktik kehidupan sosio-kultural manusia Maluku. Tradisi Pela Gandong menawarkan fondasi nilai kehidupan dan resolusi bagi konflik sekterian di Maluku. Persatuan, kesatuan dan rasa persaudaraan yang berkelanjutan dirawat dalam tradisi Pela. Kebudayaan Maluku terkhusus dalam praktik Pela mencerminkan fungsi nilai-nilai yang dapat mempersatukan perbedaan, mendamaikan permusuhan, dan mengeratkan persaudaraan. Nilai-nilai pada Pela dapat diabstrakkan menjadi nilai yang umum yakni nilai kemanusiaan. Secara global nilai kemanusiaan telah menjadi nilai yang bersifat pokok dan utama bagi berjalannya kehidupan di berbagai negara demokratis.

Narasi Etis Pela Gandong bersifat luhur dan sekaligus fungsional menjaga kohesi sosial masyarakat Maluku. Pela Gandong sebagai puncak-puncak kebudayaan nasional berfungsi juga sebagai inspirasi bagi prinsip dan sikap menjunjung persatuan dan kemanusiaan. Nasionalisme Indonesia harus terus menjadikan budaya-budaya lokal di daerah sebagai kekuatan dalam rangka menjaga persatuan bangsa. Upaya menghargai dan melestarikan budaya lokal semestinya menjadi faktor penting, sebab identitas nasionalisme Indonesia terletak dalam keunikan kearifan lokal di daerah-daerah. Falsafah bangsa Indonesia dapat menjadi medium pertemuan ragam kearifan lokal. Modal itulah yang harus digunakan maksimal untuk membingkai kehidupan bernegara dan berbangsa.

\section{DAFTAR PUSTAKA}

Akhyat, Arif. 2019. Explaining a Narrative in Critical Philosophy of History. Jurnal Filsafat, Vol. 29. No. 2.

Asmarani, Ni Nyoman, 2020. Kurban Hewan Dalam Upacara Yadnya: Membunuh Atau Memuliakan? Jurnal Filsafat, Vol. 30. No 1.

Bakker, Anton. 1995. Antropologi Metafisik. Yogyakarta: Kanisius. 
Bakker, J.W.M. 1984. Filsafat Kebudayaan: sebuah pengantar. Yogyakarta: Kanisius.

Bartels, Dieter. 2019. Di Bawah Naungan Gunung Nunusaku. Jakarta: Gramedia.

Bin-Tahir S.Z., Hanapi, Hanapi. 2019. Revitalizing the Maluku Local Language in Multilingual Learning Model. International Journal of Scientific Technology Research, Vol. 8. Issue 10. October 2019.

Dewey, John. 1998. Budaya dan Kebebasan: Ketegangan Antara Kebebasan Individu dan Aksi Kolektif. Jakarta: Yayasan Obor Indonesia.

Fitri, Alfariz, 2020. Tradisi Panai dalam Perspektif Nilai. Jurnal Filsafat Indonesia, Vol. 3, No.2

Hasudungan, Anju. 2019. Peace Education on Local Wisdom of Pela Gandong in Social Science. International Journal of Social, Politics, and Humanities, Vol. 3, No. 2, October 2020

Hehanussa, JMN. 2009. Pela dan Gandong: Sebuah Model Kehidupan Bersama. Jurnal Gema Teologi, Vol. 33. No.1

Koentjaraningrat. 2004. Kebudayaan, Mentalitas dan Pembangunan. Jakarta: Gramedia.

Leirissa, R.Z. 1982. Maluku Tengah di Masa Lampau. Arsip Nasional Republik Indonesia, Jakarta.

Masringor, J. 2017. Pela Gandong Sebagai Sarana Penyelesaian Konflik. Jurnal Perspektif, Vol 22. No1. Notonegoro, 1995. Pancasila Secara Ilmiah Populer. Jakarta: Bumi Aksara.

Ruhulessin, J. 2019. Paradigma Etika Publik dalam Kearifan Lokal Pela. Jurnal Fisafat, Vol. 29. No 2.

Sarnely, Suge. 2019. Development of Social Studies Learning Model Based on Local Wisdom in Improving Students' Knowledge and Social Attitude. International Journal of Instruction, Vol.12, No.3. July 2019.

Sinnerbrink, Robert. 2020. A Philosophy of Cultural Modernity: Márkus's Contribution to the Philosophy of Culture. Journal of Critical Theory and Historical Sociology, Vol 160. No.1. October 1, 2020.

Snijders, Adelbert. 2004. Antropologi Filsafat Manusia: Paradoks dan Seruan. Yogyakarta: Kanisius. Soeprapto, 1995. Aktualisasi Nilai-Nilai Pancasila Notonegoro. Jurnal Filsafat, seri 22 Agustus 1995.

Tangidy, Martin. 2016. Toleransi Melalui Model Budaya Pela Gandong Menggunakan Media Board Game Untuk Mahasiswa. Jurnal Sabda, Vol 11, No 2, Desember 2016.

Titaley, Elsina. 2018. Pela Gandong Culture as Basic of A Network Formation For Poverty Alleviation In The Village. Advances in Social Sciences Research Journal, Vol.5, No.3.

Tjahya Putri, C Elly Kumari. 2014. Pelestarian Tradisi dan Budaya Pela Gandong Bagi Pencegahan Konflik Sosial di Kota Ambon. Jurnal Penelitian Kesejahteraan Sosial, Vol. 13. No. 12014.

Tutuhatumewa, A R, 2010. Budaya Pela di Maluku: Sebuah Model Komunikasi Antar Budaya dan implikasinya bagi Pengolahan Konflik Antar Masyarakat. Jurnal Ilmu-IImu Sosial "Badati".

Van Peursen. 2003. Menjadi Filsuf: Suatu Pendorong ke Arah Berfilsafat Sendiri. Yogyakarta: CV. Qalam. 